\title{
Gambaran Kegagalan Perbaikan CD4 Pasien Koinfeksi TB-HIV Berdasarkan Jarak Waktu Pemberian Antiretroviral Pasca Obat Anti Tuberkulosis di Rumah Sakit Penyakit Infeksi (RSPI) Prof. Dr. Sulianti Saroso
}

\author{
Description of C4 Response Failure in TB-HIV Co-infection Patients Based on \\ Time to Antiretroviral After Taking Anti Tuberculosis Treatment in Infectious \\ Disease Hospital Prof. Dr. Sulianti Saroso
}

\author{
Musdalifah $^{1^{*}}$, Ratna Djuwita ${ }^{2}$, Adria Rusli ${ }^{3}$, Mondastri Korib ${ }^{2}$ \\ ${ }^{1}$ Pascasarjana Epidemiologi, Fakultas Kesehatan Masyarakat, Universitas Indonesia, \\ ${ }^{2,4}$ Departemen Epidemiologi, Fakultas Kesehatan Masyarakat, Universitas Indonesia, \\ ${ }^{3}$ Rumah Sakit Penyakit Infeksi Prof. Dr. Sulianti Sarosos Jakarta,
}

*Korespondensi Penulis :

Musdalifah

Email : musdalifah_rizky@yahoo.co.id

\begin{abstract}
Abstrak
Latarbelakang : Memulai terapi Antiretroviral (ARV) lebih awal berisiko menimbulkan interaksi Obat Anti TB (OAT) dengan ARV, efek samping obat, keracunan akibat obat, tantangan kepatuhan minum obat dan terjadinya Immune Reconstitution Inflammatory Syndrome (IRIS).

Metode : Penelitian ini menggunakan design penelitian kohort restrospektif dengan follow-up selama satu setengah tahun. Penelitian dilaksanakan di Rumah Sakit Penyakit Infeksi (RSPI) Prof. Dr. Sulianti Saroso Tahun 2016. Populasi studi adalah pasien Ko-infeksi TB-HIV yang naive ART dan tercatat pada rekam medis periode Januari 2010 - November 2014. Data pasien diperoleh dari rekam medis pasien dengan kriteria inklusi sampel adalah pasien usia $\geq 15$ tahun, mendapat OAT minimal 2 minggu sebelum ART dimulai, dan memiliki data hasil pemeriksaan CD4 sebanyak dua kali dengan total sampel sebanyak 164 orang.

Hasil : Probabilias kumulatif kegagalan perbaikan CD4 pasien ko-infeksi TB-HIV sebesar 14,43\%. Hazard rate kegagalan perbaikan CD4 pada pasien yang memulai terapi ARV 2-8 minggu setelah OAT dibandingkan dengan yang menunda terapi ARV 8 minggu setelah OAT masing-masing 767 per 10.000 orang tahun dan 447 per 10.000 orang tahun $(p=0,266)$.

Kesimpulan : Hazard rate kegagalan perbaikan CD4 pada pasien yang memulai terapi ARV 2-8 minggu setelah OAT lebih tinggi dibandingkan dengan hazard rate pada pasien yang menunda terapi ARV 8 minggu setelah OAT.
\end{abstract}

Kata kunci : Ko-infeksi TB-HIV, ART, kegagalan perbaikan CD4

\begin{abstract}
Background : Starting Antiretroviral Treatment (ART) earlier was assosiated to pharmacologic interactions, side effect, high pill burden, treatment interruption, and Immune Reconstitution Inflammatory Syndrome (IRIS).

Methods : This study used cohort restrospective design with one and half year time to follow up. This study was conducted from May to June 2016 at Infectious Disease Hospital Sulianti Saroso. Study population were TB-HIV coinfected patients, noted as a naive ART patient in medical records from january
\end{abstract}


2010-november 2014. A total 164 patients $\geq 15$ years old, had ATT 2 weeks before ART and had minimum 2 CD4 sell count laboratorium test results.

Result : The cumulative probability of CD4 response failure among TB-HIV co-infected patients was $14,43 \%$. Hazard rate of CD4 response failure was 767 per 10.000 person year in early ART (2-8 weeks after OAT) versus 474 per 10.000 person year in delayed ART (8 weeks after OAT) $(p=0,266)$.

Conclusion : Hazard CD4 repair failure rate in patients who started ARV therapy 2-8 weeks after OAT higher than the hazard rate in patients who deferred antiretroviral therapy 8 weeks after OAT.

Keywords : TB-HIV Co-infection, Antiretroviral treatment, CD4 response failure

\section{Pendahuluan}

Koinfeksi antara Tuberkulosis

(TB) dan Human Immunodeficiency

Virus (HIV) memberikan tantangan berat dalam program penangan kasus TB-HIV. ${ }^{1}$ Infeksi HIV yang progresif akan menurunkan sistem kekebalan tubuh yang progresif melalui penurunan jumlah dan kinerja fungsi limfosit-T sel CD4. ${ }^{2}$ Interaksi antara Tuberkulosis (TB) dan Human Immunodeficiency Virus (HIV) menghasilkan hubungan yang sindemik. Konsekuensi dari interaksi sindemik TB dan HIV adalah kematian. ${ }^{3}$ Seseorangyang baru didiagnosa terinfeksi TB setidaknya 19 kali lebih berisiko untuk terinfeksi HIV dibandingkan dengan individu yang tidak terinfeksi TB. Sebaliknya seorang ODHA berisiko 20-30 kali untuk mengalami TB dibandingkan individu yang tidak terinfeksi HIV. ${ }^{3}$ World Health Organization (WHO) memperkirakan jumlah pasien koinfeksi TB-HIV di dunia sebanyak 14 juta orang dan sekitar 3 juta pasien koinfeksi TB-HIV tersebut terdapat di Asia Tenggara. ${ }^{2}$ Sebagai salah satu dari 41 negara dengan beban tinggi TB-HIV, Indonesia memiliki prevalensi HIV pada kasus TB baru sebesar $3,1 \%$, dengan beberapa provinsi yang prevalensinya lebih tinggi, seperti Papua (14\%) dan Bali (3,9\%). ${ }^{4}$

Tantangan lain pada pasien koinfeksi TB adalah pemilihan waktu yang tepat untuk memulai ART. Memulai ART lebih awal memiliki risiko terjadinya interaksi Obat Anti TB (OAT) dengan ART, efek samping obat, keracunan akibat obat, tantangan kepatuhan minum obat dan terjadinya Immune Reconstitution Inflammatory Syndrome (IRIS). ${ }^{5,6,7}$ Di sisi lain, penundaan untuk memulai ART juga bisa menimbulkan keparahan atau terjadinya AIDS bahkan kematian. ${ }^{5,7}$ Pengobatan ART yang tertunda dapat meningkatkan kejadian kegagalan imunologis pada pasien koinfeksi TBHIV. $^{8}$ Dengan demikian perlu pertimbangan yang tepat antara risiko dan manfaat memulai ART lebih awal atau menundanya.

Hasil penelitian di Ethiopia menemukan bahwa prevalensi terjadinya kegagalan imunologis pasien HIV yang menggunakan ARV sebesar $17,11 \%$. Angka kegagalan imunologis 
pada pasien HIV mencapai 8,5 per 100 orang tahun., ${ }^{9,10}$ Penelitian tentang kegagalan perbaikan CD4 pasien berdasarkanjarak waktu pemberian ARVbelum pernah dilakukan di RSPI. Berdasarkan penjelasan tersebut, perlu dilakukan penelitian untuk menjawab pertanyaan penelitian bagaimana gambaran hazard rate kegagalan perbaikan CD4 pasien koinfeksi TB HIV berdasarkan jarak waktu pemberian ARV setelah OAT diberikan.

\section{Metode}

Penelitian deskriptif dengan analisis survival dengan design kohort retrospektif. Penelitian ini dilakukan selama 2 bulan yaitu Mei-Juni 2016 dengan menggunakan rekam medis pasien. Populasi studi pada penelitian ini adalah semua pasien yang didiagnosa mengalami koinfeksi TBHIV dan berusia 15 tahun atau lebih dan tercatat sebagai pasien naive ARV pada rekam medis atau catatan lainnya di RSPI Sulianti Saroso, pada periode Januari 2010 hingga November 2014. Kriteria inklusi sampel adalah pasien usia $\geq 15$ tahun, mendapat OAT sebelum terapi ARV, dan memiliki data hasil pemeriksaan CD4 sebanyak dua kali. Pasien ko-infeksi TB-HIV yang memulai pengobatan ARV kurang dari 2 minggu setelah OAT dimulai, pasien koinfeksi dengan TB MDR, hamil selama pengamatan, memiliki riwayat diabetes melitus, atau tidak mempunyai data/ catatan rekam medis yang lengkap dieksklusi dari penelitian. Pengambilan sampel dilakukan dengan teknik total sampling, sehingga diperoleh jumlah sampel sebanyak 164 orang.

Data penelitian yang digunakan diperoleh dari data rekam medis pasien, ikhtisar perawatan HIV dan ART, follow-up perawatan pasien dan ART, buku pra ART serta monitoring ARV. Data yang diperoleh dicatat pada lembaran kuesioner. Penelitian ini telah mendapatkan keterangan exempted dari Komite Etik Rumah Sakit Penyakit Infeksi Prof. Dr. Sulianti Saroso Jakarta.Untuk mengurangi bisa seleksi, status exsposure dan outcome pasien ditentukan dan diinput paling akhir sehingga peneliti dan enumerator di blind secara bersama-sama.Data yang terkumpul selanjutnya di analisis univariat dan bivariat dengan menggunakan survival analisis dengan bantuan software Stata 12. Probabilitas kegagalan perbaikan CD4 pasien ditampilkan dlam bentuk kurva hazard rate.

\section{Hasil}

Berdasarkan data awal dari pokja HIV RSPI Sulianti Saroso dan hasil observasi rekam medis, jumlah pasien koinfeksi TB-HIV yang naive ARV pada 
periode Januari 2011 - November 2014 sebanyak 446 pasien, namun karena tidak memenuhi kriteria inklusi (umur < 15 tahun=4 orang, terapi ARV sebelum $\mathrm{OAT}=13$ orang) atau pasien memiliki salah satu kriteria ekslusi (pasien TBMDR $=1$ orang, diabetes melitus $=1$ orang, hamil $=3$ orang, terapi $A R V<2$ minggu setelah OAT = 12 orang, data tidak lengkap $=67$ orang, periksa CD4 hanya satu kali $=48$ orang, rekam medis tidak ditemukan = 133 orang), maka jumlah sampel yang berhasil diperoleh adalah 164 orang.

Penelitian ini melibatkan 164 orang pasien ko-infeksi TB-HIV yang diamati selama satu setengah tahun (548 hari). Berdasarkan hasil penelitian diketahui, sebanyak 94 orang $(57,32 \%)$ menunda pengobatan ARV hingga fase lanjutan terapi OAT (8 minggu setelah OAT dimulai) sedangkan yang segera memulai ARV pada fase intensif OAT (2-8 minggu setelah terapi OAT dimulai) sebanyak 70 orang (42,68\%). Adapun hasil akhir pengamatan diketahui terdapat 18 orang (11\%) yang mengalami event atau kegagalan perbaikan CD4, 84 orang $(51,2 \%)$ yang tidak mengalami kegagalan perbaikan CD4 hingga akhir pengamatan dan sebanyak 62 orang $(37,8 \%)$ yang hasil akhirnya tidak diketahui. Pada kelompok pasien dengan jarak waktu pengobatan ART 2-8 minggu setelah OAT lebih banyak yang mengalami event $(14,3 \%)$ dibandingkan kelompok pasien yang menunda terapi ARV hingga 8 minggu pasca OAT dimulai (Tabel 1).

Nilai mean survival time pasien yang memulai ARV 2-8 minggu setelah OAT adalah 506, 24 hari, sedangkan pada pasien yang memulai OAT setelah 8 minggu adalah 521,83 hari (Tabel 2). Ini berarti rata-rata kegagalan imunologis pada pasien yang memulai ARV 2-8 minggu setelah OAT terjadi pada hari ke-507 sedangkan pada pasien yang memulai terapi ARV 8 minggu setelah OAT rata-rata mengalami kegagalan imunologis pada hari ke-522. Meskipun ada kecenderungan bahwa pasien koinfeksi TB-HIV yang memulai ART 8 minggu setelah OAT memiliki waktu yang lebih lama untuk mengalami kegagalan imunologis dibandingkan pada pasien yang memulai $A R V$ dalam kurun waktu 2-8 minggu setelah OAT, namun secara statistik tidak ditemukan adanya perbedaan yang bermakna (log rank test $=0,261)$. 
Tabel 1. Distribusi Frekuensi Subyek Berdasarkan Kategori Jarak Waktu Pemberian ARV Setelah OAT

\begin{tabular}{|c|c|c|c|c|c|c|c|c|}
\hline \multirow{3}{*}{$\begin{array}{c}\text { Kategori jarak waktu } \\
\text { pemberian ARV } \\
\text { setelah OAT }\end{array}$} & \multirow{2}{*}{\multicolumn{2}{|c|}{$\begin{array}{c}\text { Survive } \\
\begin{array}{c}n=84 \\
(51,2 \%)\end{array} \\
\end{array}$}} & \multicolumn{2}{|c|}{ LFU } & \multicolumn{2}{|c|}{$\begin{array}{c}\text { Event (Gagal } \\
\text { perbaikan CD4) }\end{array}$} & \multicolumn{2}{|c|}{ Total } \\
\hline & & & & & & & & \\
\hline & $\mathrm{n}$ & $\%$ & $\mathrm{n}$ & $\%$ & $\mathrm{n}$ & $\%$ & $\mathrm{n}$ & $\%$ \\
\hline 2-8 minggu & 35 & 50,0 & 25 & 35,7 & 10 & 14,3 & 70 & 42,7 \\
\hline$>=8$ minggu & 49 & 52,1 & 37 & 39,4 & 8 & 8,5 & 94 & 57,3 \\
\hline
\end{tabular}

Hasil analisis bivariat diperoleh bahwa hazard rasio terjadinya kegagalan perbaikan CD4 berdasarkan lama pemberian ARV pasca OAT adalah $0,590 \quad(95 \% \mathrm{Cl}: 0,233-1,495)$. Ini berarti pasien yang memulai terapi ARV pada 8 minggu setelah OAT diberikan memberikan efek protektif terhadap kecepatan kegagalan perbaikan CD4. Pasien yang memulai ARV pada 8 minggu setelah OAT dimulai memiliki kecepatan 0,59 kali lebih lambat dibandingkan dengan kecepatan kegagalan perbaikan CD4 pada pasien yang memulai OAT dalam kurun 2-8 minggu setelah OAT. Meskipun demikian, secara statistik pengaruh ini tidak berhubungan (Pvalue $=0,266)$ (Tabel 2).

Probabilitas kumulatif terjadinya kegagalan perbaikan CD4 (hazard rate) pasien koinfeksi TB-HIV sebesar 0,1443 atau $14,43 \%$. Ini berarti peluang kecepatan untuk terjadi kegagalan perbaikan CD4 pada 164 orang pasien selama satu setengah tahun atau 548 hari adalah 14,43\%. Jika dikonvenversikan berdasarkan perhitungan hazard per 10.000 orang tahun, maka nilai hazard rate-nya sama dengan 587 per 10.000 orang tahun. Artinya kecepatan terjadinya kegagalan perbaikan CD4 pertahun pada pasien koinfelsi TB-HIV di RSPI sulianti saroso adalah 587 per 10.000 orang tahun.

Probabilitas kumulatif hazard terjadinya kegagalan imunologis selama satu setengah tahun (548 hari) pada pasien koinfeksi TB-HIV di RSPI Sulianti Saroso yang melakukan terapi ARV 8 minggu setelah melakukan terapi OAT adalah 10,99\% sedangkan pada pasien yang melakukan terapi ARV dalam kurun waktu 2-8 minggu setelah OAT didapatkan probabilititas kumulatif hazard sebesar 18,86\%. Pada grafik terlihat dengan jelas bahwa pada awal pengamatan sampai dengan kira-kira 100 hari pengamatan, hazard rate terjadinya kegagalan perbaikan CD4 pada pasien yang memulai ART 28 minggu setelah OAT lebih rendah dibandingkan pasien yang memulai ART 8 minggu setelah OAT. Namun pada periode pengamatan kira-kira lebih dari 100 hari, hazard rate 
kegagalan perbaikan CD4 pada pasien yang memulai ART pada periode 2-8 minggu mengalami peningkatan dan melampaui bahkan selalu lebih tinggi dibandingkan dengan pasien yang memulai ART 8 minggu setelah OAT dimulai. Grafik ini senantiasa mengalami peningkatan seiring dengan berjalannya waktu. Grafik hazard rate kegagalan perbaikan CD4 1,5 tahun pasien koinfeksi TB-HIV secara kumulatif dan berdasarkan jarak waktu pemberian terapi ARV pasca OAT disajikan pada gambar 2 .

Tabel 2. Hazard rate Kegagalan Perbaikan CD4 Satu Setengah Tahun Pasien Koinfeksi TB-HIV Berdasarkan Jarak Waktu Pemberian ARV Setelah OAT

\begin{tabular}{cccccccc}
\hline \multirow{2}{*}{$\begin{array}{c}\text { Kategori jarak waktu } \\
\text { pemberian ARV } \\
\text { setelah OAT }\end{array}$} & $\begin{array}{c}\text { Mean } \\
\text { Survival } \\
\text { Time }\end{array}$ & $\begin{array}{c}\text { Log } \\
\text { rank } \\
\text { Test }(P \\
\text { value) }\end{array}$ & $\begin{array}{c}\text { Cumulativ } \\
\text { e Hazard } \\
(\%)\end{array}$ & $\begin{array}{c}\text { Hazard Rate } \\
\text { (per 10.000 } \\
\text { orang tahun })\end{array}$ & $\begin{array}{c}\text { Hazard Ratio } \\
(95 \% \mathrm{Cl})\end{array}$ & $\mathrm{P}$ \\
\hline 2-8 minggu & 506,24 & 0,261 & 18,86 & 767 & $\begin{array}{c}0,590 \\
(0,233-1,495)\end{array}$ & 0,266 \\
>= 8 minggu & 521,83 & & 10,99 & 447 & & \\
\hline
\end{tabular}

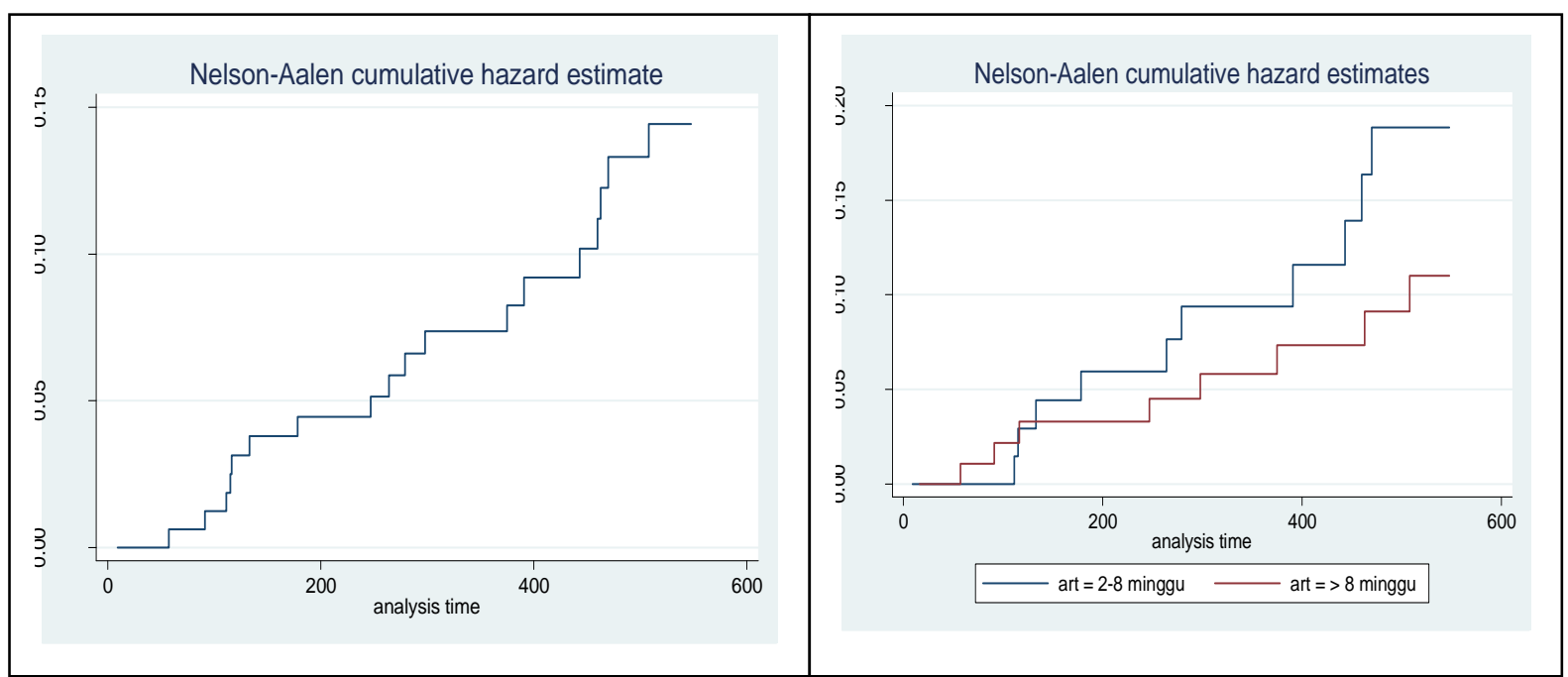

Gambar 2. Grafik Hazard Rate Kegagalan Perbaikan CD4 Pasien Koinfeksi TB-HIV Selama 1,5 Tahun Secara Kumulatif (kiri) dan Berdasarkan Jarak Waktu Pemberian ARV Pasca OAT (kanan)

\section{Pembahasan}

Pada pasien HIV yang sedang menjalani pengobatan TB dengan Rifampisin, penggunaan ARV dikhawatirkan dapat mengalami interaksi obat dan mengalami efek samping obat yang buruk disebabkan efek samping Rifampisin dan ARV yang hampir sama. Pasien koinfeksi TB-HIV yang belum memulai pengobatan ARV, 
dianjurkan untuk segera memulai terapi OAT dan memulai pengobatan ARV sesegera mungkin setelah OAT, paling cepat 2 minggu dan paling lambat 8 minggu setelah OAT diberikan dan dapat ditoleransi telah direkomendasikan oleh WHO. ${ }^{11}$

Hazard rate terjadinya kegagalan perbaikan CD4 pasien koinfeksi TB-HIV di RSPI Sulianti Saroso pada 6 bulan, 12 bulan dan 18 bulan pengamatan berturut-turut sebesar 4,45\%, 7,37\% dan $14,43 \%$ atau masing-masing sebesar 543 per 10.000 orang tahun, 450 per 10.000 orang tahun dan 587 per 10.000 orang tahun. Artinya, pada 6 bulan pertama follow-up, rate terjadinya kegagalan perbaikan CD4 sama dengan 543 per 10.000 orang tahun sementara pada bulan ke-12 rate kegagalan perbaikan CD4 agak menurun menjadi 450 per 10.000 orang tahun dan pada pengamatan ke-18 bulan rate kegagalan perbaikan CD4 kembali menjadi 587 per 10.000 orang tahun. Angka ini jauh lebih rendah jika dibandingkan dengan hasil penelitian di Ethiopia, dimana rate kegagalan imunologis pada pasien HIV mencapai 20,1 per 100 orang tahun (2.010 per 10.000 orang tahun) pada satu tahun pertama follow up dan 13,0 per 100 orang tahun (1.300 per 10.000 orang tahun) setelah dua tahun follow-up. ${ }^{10}$ Pada 6 bulan pertama pengamatan, 7 dari 164 orang mengalami kegagalan perbaikan CD4 karena terjadi penurunan jumlah sel CD4. Empat orang diantaranya merupakan pasien yang memulai ART lebih awal.

Hasil penelitian menunjukkan bahwa rate kegagalan perbaikan CD4 pada pasien koinfeksi TB-HIV di RSPI Sulianti Saroso yang melakukan terapi ARV 8 minggu setelah melakukan terapi OAT lebih rendah dibandingkan dengan rate kegagalan perbaikan CD4 pasien yang memulai ARV pada 2-8 minggu setelah OAT $(10,99 \%$ dan $18,86 \%$ dengan nilai $P=0,261)$. Hasil penelitian ini berbeda dengan penelitian RCT yang dilakukan oleh Sinha di India yang menemukan bahwa secara umum rate kegagalan terapi ARV dua kali lebih cepat pada kelompok ODHA yang menunda pengobatan ARV hingga 8-12 minggu setelah pengobatan OAT dimulai dibandingkan dengan ODHA yang memulai ART lebih cepat yaitu 24 minggu setelah OAT dimulai (masingmasing $31 \%$ dan $16 \%$ dengan nilai $P=0,045)$. Perbedaan ini dimungkinkan karena pada penelitian ini, Sinha menggunakan rate kegagalan terapi secara umum, bukan rate kegagalan imunologis ataupun perbaikan CD4 secara khusus. Adapun indikator kegagalan terapi yang digunakan oleh Sinha adalah perkembangan penyakit 
HIV, dimana terjadi progresifitas perjalanan penyakit HIV. ${ }^{8}$

Hasil analisis bivariat
menunjukkan bahwa waktu inisiasi ARV 8 minggu setelah OAT dimulai memberikan efek protektif terhadap kegagalan perbaikan $\mathrm{CD} 4$ ( $\mathrm{cHR}=0,590$, 95\% Cl: 0,233-1,495), namun tidak berpengaruh secara signifikan $(\mathrm{p}=$ $0,226)$ serta dengan range nilai $95 \%$ confident interval $(\mathrm{Cl})$ yang melewati angka 1 (null value). Hal ini menunjukkan bahwa hubungan protektif yang terjadi mungkin saja karena faktor kebetulan (chance), atau karena jumlah event pada penelitian ini yang terbilang sedikit. ${ }^{12}$ Hasil penelitian ini tidak sesuai dengan hipotesis awal bahwa pada pasien yang memulai ARV 8 minggu setelah OAT dimulai akan mengalami kegagalan perbaikan CD4 yang lebih cepat dibandingkan dengan pasien yang memulai ARV pada 2-8 minggu setelah OAT diberikan. Hal ini mungkin disebabkan oleh karena pasien yang memulai terapi ARV lebih awal biasanya merupakan pasien dengan kondisi tertentu seperti ada koinfeksi dengan infeksi opportunistik (IO) lain atau memang sudah dalam kondisi immunosupresi sehingga dokter menyarankan segera terapi dan pasien pun mau segera memulai pengobatan ART.
Hasil penelitian yang tidak sesuai dengan hasil penelitian Sinha, mungkin juga disebabkan karena kegagalan perbaikan CD4 pada penelitian ini diukur sejak awal pengamatan, hal ini kurang sesuai dengan kriteria WHO dimana pemantauan CD4 pasien sebagai respon terapi ARV dapat dilakukan setelah 6 bulan terapi ARV.

Meskipun hasil penelitian ini tidak menunjukkan pengaruh signifikan antara waktu memulai ARV terhadap kegagalan perbaikan CD4 pasien, namun pada pasien yang memulai ARV lebih awal terdapat kecenderungan kenaikan jumlah sel CD4 yang lebih tinggi dibandingkan pada pasien yang menunda ART. Selain itu, berdasarkan hasil penelitian di RSPI Sulianti Saroso sebelumnya, diketahui bahwa pasien koinfeksi TB-HIV yang menunda ARV hingga fase intensif selesai memiliki risiko kematian yang lebih cepat dengan adjusted HR 2,40 $(95 \% \mathrm{Cl}$; 1,29-4,46; $\quad \mathrm{p}=0,006)$ dibandingkan pasien yang memulai pengobatan ARV pada fase intensif pengobatan TB. ${ }^{13}$ Oleh karenanya, memulai ARV segera setelah OAT dapat ditoleransi tetap perlu dilakukan.

\section{Kesimpulan}

Probabilias kumulatif kegagalan perbaikan CD4 pasien koinfeksi TB-HIV di RSPI Prof. Dr. Sulianti Saroso selama 1,5 tahun sebesar $14,43 \%$. 
Hazard rate kegagalan perbaikan CD4 pada pasien yang memulai terapi ARV 2-8 minggu setelah OAT lebih tinggi dibandingkan dengan hazard rate pada pasien yang menunda terapi ARV 8 minggu setelah OAT masing-masing 767 per 10.000 orang tahun dan 447 per 10.000 orang tahun $(p=0,266)$. Menunda terapi ARV hingga 8 minggu setelah OAT dimulai memberikan efek proteksi terhadap keggalan perbaikan CD4, namun hubungan ini tidak signifikan.

\section{Ucapan Terima Kasih}

Penulis mengucapkan terima kasih kepada RSPI Prof Dr. Sulianti Saroso dan semua pihak yang terlibat atas konstribusi dan bantuan dalam proses pengumpulan dan analisa data.

\section{Daftar Pustaka}

1. World Health Organization. Global summary of the AIDS Epidemic. [Internet] 2015 [cited 08 April 2016]. Available from: http://www.who.int/hiv/data/epi_cor e_july2015.png

2. Kementerian Kesehatan Republik Indonesia. Petunjuk Teknis Tata Laksana Klinis Ko-infeksi TB-HIV. Direktorat Jenderal Pengendalian Penyakit dan Penyehatan Lingkungan. Jakarta ; 2012

3. Kwan KC and Ernst DJ. HIV and Tuberculosis: a Deadly Human Syndemic. Clinical Microbiology Review. Apr. 2011, p.351-376. [Internet] 2011 [cited 08 April 2016]. Available from http://www.ncbi.nlm.nih.gov/pmc/ar ticles/PMC3122491/pdf/zcm351.pd f.

4. World Health Organization. TB-HIV Indonesia ; Update, 2014. [Internet] 2011 [cited 02 Februari 2016].

http://www.searo.who.int/indonesia/ topics/tbindonesiaupdate2014/en/

5. Velasco $M$ et al. Effect of Simultaneous Use of Highly Active Antiretroviral Therapy on Survival of HIV Patients With Tuberculosis. 2009. J Acquir Immune Defic Syndr Volume 50, Number 2, February $\overline{1}$, 2009. [Internet] 2009[cited 13 Oktober 2015].

6. World Health Organisation. Guideline on When to Start Antiretroviral Theraphy and on PreExposure Prophylaxis for HIV. [Internet] 2015[cited 03 Maret 2016]. Available from: http://apps.who.int/iris/bitstream/10 665/186275/1/9789241509565_en g.pdf

7. Naidoo K, Baxter C, Karim SSA. When to start antiretroviral therapy during tuberculosis treatment. Curr Opin Infect Dis. 2013 February ; 26(1): $35-42$. doi:10.1097/QCO.0b013e32835ba 8f9. [internet] 2013 (cited 08 Oktober 2015). Available from: http://www.ncbi.nlm.nih.gov/pmc/ar ticles/PMC3616247/pdf/nihms4485 58.pdf

8. Sinha S, et al. Early versus delayed initiation on antiretroviral therapy for indian HIV infected individual with tuberculosis on antituberculosis treatment. BMC infectius disease 2012, 12:168. [Internet] 2012 [cited 28 Februari 2016]. Available from: http://www.biomedcentral.com/147 $1-2334 / 12 / 168$ 
9. Yirdaw $K D$ and Hattingh $S$. Prevalence and Predictors of Immunological. Failure among HIV Patients on HAART in Southern Ethiopia. PLOS ONE DOI:10.1371/journal.pone.0125826 . [Internet] 2015. [cited 04 januari 2016] Available from: http://journals.plos.org/plosone/arti cle $? \mathrm{id}=10.1371 /$ journal.pone .01258 26.

10. Assefa, A., gelawa B, Getnet G, and Yitayew $G$. The Effect of Incident Tuberculosis on Immunological Response of HIV Patients on Highly Active Antiretroviral Therapy at Gondar University Hospital, Northwest Ethiopia: A Retrospective Followup Study. BMC Infectious Disease 2014, 14:468 [Internet] 2014 [cited 01 April 2016] http://www.biomedcentral.com/147 $1-2334 / 14 / 468$

11. World Health Organization. Consolidated guidelines on the use of antiretroviral drugs for treating HIV infection. [Internet] 2013 [cited 01 April 2016]. Available from: http://www.who.int/hiv/pub/guidelin es/arv2013/download/en/index.html

12. Elwood M. Critical Appraisal of Epidemilogical Studies and Clinical Trials. Oxford: Oxford University Press; 2007.

13. Maemun S. 2015. Pengaruh Waktu Awal Pengobatan Antiretroviral (ARV) Terhadap Ketahanan Hidup Satu Tahun Pasien Ko-infeksi TBHIV di Rumah Sakit Penyakit Infeksi Prof. Dr. Sulianti Saroso Periode Januari 2011-Mei 2014. [Tesis] Depok. Fakultas Kesehatan Masyarakat, Universitas Indonesia, 2015. 